\title{
乳化肪添加油脂のクリーミング性および 吸水性について
}

\author{
（第 2 報）プロピレングリコール脂肪酸エステル，ソルビタン \\ モノ脂肪酸エステル，ポリオキシソルビタンモノ脂肪 \\ 酸エステル添加の效果
}

丸山武紀*・木下葉子*・新谷 期 $^{*}$ ・ 今村正男*

Creaming and Water-Sorption Quality of Oils and Fats Added with Emulsifiers

Part II. Effect of propylen glycol ester of fatty acid, sorbitan mono-fatty acid ester and polyoxyethylene sorbitan mono-fatty acid ester

Takenori Maruyama, Yoko Kinoshita, Isao Niya and Masao Imamura

The effect of four kinds of emulsifiers on the creaming and water-sorption quality in edible solid fats was investigated. Addition of Homotex or Tween 80 increased the creaming value and showed the effect of tempering. Although the samples added with Span 80 or Span 20 showed no different tendency from control which did not contain emulsifier at the initial stage of creaming but showed good continuance.

Hardened soybean oil and hardened whale oil added with Homotex showed good water-sorption quality but beef tallow did not. Addition of Span 80, Span 20 or Tween 80 was undesirable for water-sorption quality and there was no effect depending on the amount of emulsifiers added.

(Received Nov. 30, 1972)

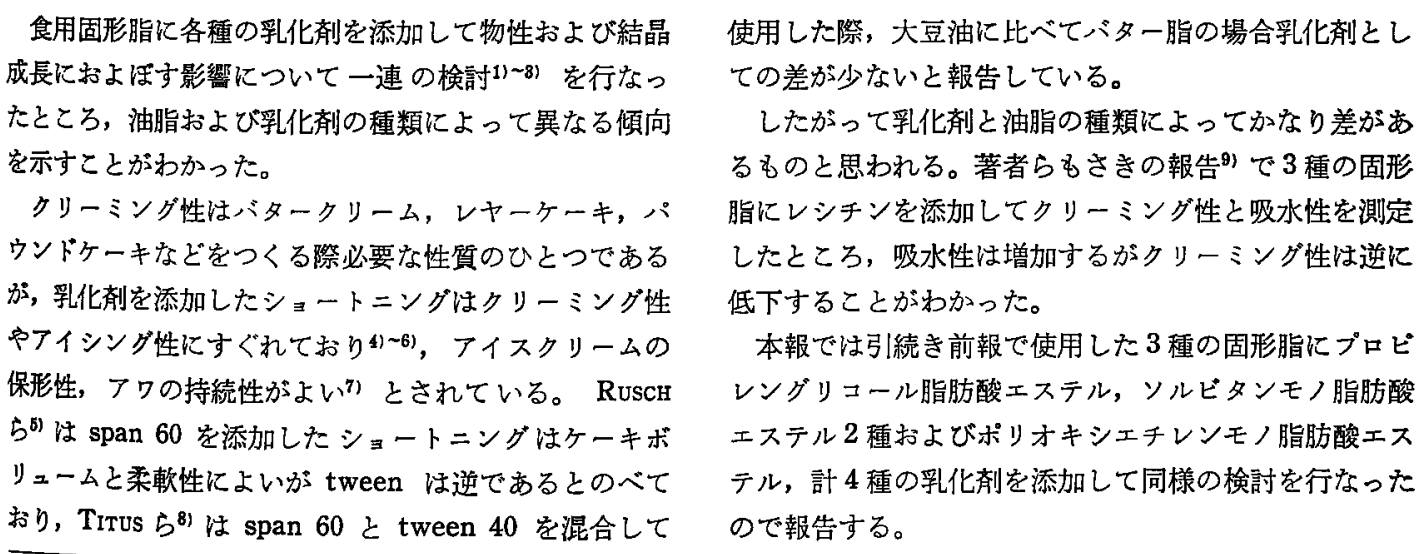

\footnotetext{
* 財団法人 日本食品油脂検査協会 (東京都中央区日本橋浜町 3-27-8)

* Japan Institute of Oils \& Fats, Other Foods Inspection (Foundation) Chuo-ku, Tokyo.
} 


\section{試料および実験方法}

\section{1. 試 料}

食用固形脂はさきの報告9)で使用した硬化大豆油，牛 㴯および硬化鯨油の 3 種類である。

乳化削はプロピレングリコール脂肪酸エステル (homotex), ソルビタンそ/オレインエステル（span 80), ソルビタンモノラウリンエステル( $\operatorname{span} 20)$, ポリ オキェチレンソルビタンモノオレインエステル（tween 80)の 4 種類で，一般性状は Table 1 亿示すとおりで ある。前記固形脂に homotex, span 80 は $0.5,1,3$, $5,10 \%$, span 20 および tween 80 はそれぞれ 1，3， $5 \%$ 添加した。

\section{2. 実験方法}

前報同様に $25^{\circ} \mathrm{C}$ に $24,120,240 \mathrm{hr}$ テンパリングし たものについて, 上昇融点 $(\mathrm{mp})$ ), 固体脂指数（以下 S.F. I.),クリーミング価および吸水量指数の測定を行なった。

実験結果および考察

1. 融点, S.F.I. 測定結果

(1) 融点測定結果

硬化大豆油の融点は Table 2 に示すように, 乳化削 の添加量が增えるにしたがって低くなる。しかし $240 \mathrm{hr}$ 後の融点変化をみると， homotex の添加量が増えるに 従い変化が少なくなり結晶成長抑制効果のあることは前 にも結晶成長と乳化用の関連について述べたとおりであ る3)。しかし $\operatorname{span} 80$, span 20 を添加すると融点法上 昇しており，前に促進効果があると報告”した事実と一

Table 1. Properties and fatty acid composition of emulsifiers used for experiments

\begin{tabular}{|c|c|c|c|c|c|c|c|c|c|c|c|c|c|c|c|c|c|c|c|}
\hline \multirow{2}{*}{ Emulsifier } & \multirow{2}{*}{ A.V. } & \multirow{2}{*}{ S.V. } & \multirow{2}{*}{ I.V. } & \multicolumn{16}{|c|}{ Fatty acid $(\%)$} \\
\hline & & & & $\mathrm{C}_{6: 0}$ & $\mathrm{C}_{8 ; 0}$ & $C_{10: 0}$ & $C_{12: 0}$ & $C_{11: 0}$ & $C_{14: 1}$ & $C_{16: 0}$ & $C_{16: 0}$ & $C_{16: 1}$ & $C_{17: 0}$ & $\mathrm{C}_{17: 1}$ & $C_{18: 0}$ & $C_{18: 1}$ & $\mathrm{C}_{18: 2}$ & $C_{18: 8}$ & $C_{2 n: 0}$ \\
\hline Homotex & 1 & 163 & 0 & & & & 1.3 & 1.4 & & $\operatorname{tr}$ & 7.3 & & 0.7 & & 82.3 & 4.8 & 1.5 & 0.7 & \\
\hline Span 80 & 8 & 156 & 66 & & & 0.2 & 0.3 & 3.4 & 2.1 & 0.6 & 6.1 & 6.9 & 0.6 & 1.8 & 1.9 & 60.0 & 11.7 & 2.6 & 1.6 \\
\hline Span 20 & 9 & 166 & 3 & 0.8 & 4.4 & 6.6 & 54.8 & 16.6 & & & 8.9 & 1.0 & 1.0 & & 2.3 & 3.6 & $\mathrm{tr}$ & & \\
\hline Tween 80 & 4 & 53.7 & 22 & & $\operatorname{tr}$ & tr & 3.9 & 3.1 & & & 8.7 & 11.3 & 3.9 & & 7.2 & 53.3 & 8.8 & & \\
\hline
\end{tabular}

Homotex: Propylen glycol ester of fatty acid.

Table 2. Melting point and S.F.I. of solid fat with emulsifiers

\begin{tabular}{|c|c|c|c|c|c|c|c|c|c|c|c|c|c|}
\hline \multirow{3}{*}{ Emulsifier } & \multirow[b]{3}{*}{$\%$} & \multicolumn{4}{|c|}{ Hardend soybean oil } & \multicolumn{4}{|c|}{ Beef tallow } & \multicolumn{4}{|c|}{ Hardend whale oil } \\
\hline & & \multicolumn{2}{|c|}{ mp. $\left({ }^{\circ} \mathrm{C}\right)$} & \multicolumn{2}{|c|}{ S.F.I. } & \multicolumn{2}{|c|}{ mp. $\left({ }^{\circ} \mathrm{C}\right)$} & \multicolumn{2}{|c|}{ S.F.I. } & \multicolumn{2}{|c|}{ mp. $\left({ }^{\circ} \mathrm{C}\right)$} & \multicolumn{2}{|c|}{ S.F.I. } \\
\hline & & $24 \mathrm{hr}$ & $240 \mathrm{hr}$ & $21 \mathrm{hr}$ & $240 \mathrm{hr}$ & $24 \mathrm{hr}$ & $240 \mathrm{hr}$ & $24 \mathrm{hr}$ & $240 \mathrm{hr}$ & $24 \mathrm{hr}$ & $240 \mathrm{hr}$ & $24 \mathrm{hr}$ & $240 \mathrm{hr}$ \\
\hline \multirow{5}{*}{ Homotex } & 0.5 & 35.1 & 36.4 & 24.1 & 24.5 & 41.6 & 41.8 & 16.4 & 17.2 & 32.6 & 33.0 & 19.8 & 19.7 \\
\hline & 1 & 35.2 & 35.6 & 23.3 & 24.4 & 42.0 & 42.0 & 16.4 & 17.3 & 32.8 & 33.2 & 19.4 & 19.6 \\
\hline & 3 & 34.7 & 35.0 & 21.6 & 21.6 & 41.6 & 41.7 & 16.3 & 17.1 & 32.1 & 32.5 & 16.7 & 16.6 \\
\hline & 5 & 34.5 & 34.8 & 21.4 & 21.6 & 41.4 & 41.4 & 15.0 & 15.9 & 31.9 & 32.4 & 16.6 & 16.6 \\
\hline & 10 & 34.2 & 34.5 & 20.2 & 20.6 & 40.3 & 40.4 & 13.9 & 14.3 & 31.9 & 32.4 & 15.5 & 15.6 \\
\hline \multirow{5}{*}{ Span 80} & 0.5 & 35.9 & 37.4 & 27.4 & 27.4 & 41.9 & 42.1 & 21.9 & 21.8 & 33.1 & 33.9 & 19.5 & 19.8 \\
\hline & 1 & 35.6 & 37.1 & 25.8 & 26.0 & 41.6 & 42.3 & 21.5 & 21.6 & 32.6 & 33.9 & 19.4 & 19.4 \\
\hline & 3 & 35.1 & 36.1 & 23.8 & 24.2 & 41.3 & 41.4 & 20.6 & 20.5 & 32.8 & 33.5 & 18.3 & 18.3 \\
\hline & 5 & 34.5 & 36.1 & 21.6 & 22.4 & 41.1 & 41.2 & 20.4 & 20.3 & 32.7 & 33.4 & 17.8 & 17.6 \\
\hline & 10 & 34.4 & 36.0 & 21.3 & 23.1 & 40.8 & 40.9 & 18.5 & 18.4 & 32.8 & 33.6 & 16.3 & 16.1 \\
\hline \multirow{3}{*}{ Span 80} & 1 & 35.2 & 36.9 & 25.6 & 25.9 & 4]. 4 & 42.0 & 21.6 & 21.5 & 32.6 & 33.0 & 19.8 & 19.8 \\
\hline & 3 & 35.0 & 36.1 & 24.9 & 26.2 & 41.1 & $\$ 1.6$ & 21.6 & 21.4 & 32.5 & 33.4 & 18.7 & 18.5 \\
\hline & 5 & 34.0 & 35.9 & 24.2 & 26.9 & 41.1 & 41.4 & 20.0 & 20.0 & 32.6 & 33.6 & 18.1 & 18.0 \\
\hline \multirow{3}{*}{ Tween 80} & 1 & 35.2 & 35.7 & 25.7 & 25.6 & 41.3 & 41.7 & 21.5 & 21.6 & 32.8 & 33.2 & 19.8 & 19.7 \\
\hline & 3 & 34.6 & 35.2 & 25.3 & 26.1 & 40.7 & 41.2 & 21.3 & 21.3 & 32.9 & 33.1 & 19.7 & 19.6 \\
\hline & 5 & 34.0 & 34.5 & 24.1 & 26.8 & 40.2 & 40.5 & 20.8 & 20.8 & 33.0 & 33.1 & 19.7 & 19.6 \\
\hline
\end{tabular}


致する。

牛脂を添加量に応じてやや低くなる傾向を示し $240 \mathrm{hr}$ 後むほとんど変化しないが, 硬化鯨油は添加量による差 がほとんどみられない。

(2) S.F.I. 測定結果

Table 2 に示すように, テンパリング $24 \mathrm{hr}$ で比較す ると，いずれる源加量が増すにしたがい S.F.I. 值は小 さくなり，牛脂および硬化鯨油では $240 \mathrm{hr}$ テンパリン グ後もほとんど変化がみられず結晶成長には関与しない ことを示している。

硬化大豆油もテンパリング $24 \mathrm{hr}$ では融点の傾向と同 様添加量に応じて低い值を示す。しかし $240 \mathrm{hr}$ 後で みると, homotex の添加量が多くなるにつれて融点の 㑯向からも予想されるが結晶成長を抑制する効果がある ため変化がみられなくなり， span 80, span 20, tween 80 で增加の傾向宗している。

2. クリーミング価

\section{(1) Homotex 添加試料 \\ i) 硬化大豆油}

$25^{\circ} \mathrm{C}$ に $24 \mathrm{hr}$ テンパリングした試料のクリーミング価 は Fig. 1 に示すように，添加量が増すほど大きい值を 示し良好な結果が得られた。10\%添加すると $163 \rightarrow 209$ と約 30\% 抱気性 が增大するととすに持続性も非常に良 好となる。Table 2 に示すように添加により S.F.I. が 小さくなり，逆にクリーミング価は大きくなる傾向を示 す。

また, テンパリング時間の勃果は Table 3 に示すよ うに, $240 \mathrm{hr}$ 後の試料はさらに抱気性が良好となり，添 加量 $3 \%$ ののではとくにその効果が認められテンパ リング $24 \mathrm{hr}$ のものよりクリーミング価は $26 \%$ 多くな る。

ii) 牛 脂

テンパリング $24 \mathrm{hr}$ では Fig. 2 に示すように，硬化大 豆油の場合同㥞添加量が増えるに徒ってクリーミング価

Table 3. Creaming value and water-sorption index of hardened soybean oil with emulsifiers

\begin{tabular}{|c|c|c|c|c|c|c|}
\hline \multirow[t]{2}{*}{ Emulsifier } & \multirow[b]{2}{*}{ (\%) } & \multirow{2}{*}{$\begin{array}{c}\text { Tempring } \\
\text { time } \\
\text { (hr) }\end{array}$} & \multicolumn{3}{|c|}{ Creaming value } & \multirow{2}{*}{$\begin{array}{c}\text { Water-sorption } \\
\text { index }\end{array}$} \\
\hline & & & $5 \min$ & $40 \mathrm{~min}$ & $\operatorname{Max}(\min )^{*}$ & \\
\hline \multirow{5}{*}{ Homotex } & 0.5 & 24 & 135 & 171 & $172(25)$ & 20 \\
\hline & 1 & $\begin{array}{r}24 \\
240\end{array}$ & $\begin{array}{l}152 \\
145\end{array}$ & $\begin{array}{l}157 \\
179\end{array}$ & $\begin{array}{l}183(10) \\
203(25)\end{array}$ & $\begin{array}{l}20 \\
20\end{array}$ \\
\hline & 3 & $\begin{aligned} 24 \\
240\end{aligned}$ & $\begin{array}{l}165 \\
192\end{array}$ & $\begin{array}{l}181 \\
197\end{array}$ & $\begin{array}{l}185(25) \\
233(10)\end{array}$ & $\begin{array}{l}60 \\
63\end{array}$ \\
\hline & 5 & $\begin{array}{r}24 \\
240\end{array}$ & $\begin{array}{l}181 \\
157\end{array}$ & $\begin{array}{l}190 \\
216\end{array}$ & $\begin{array}{l}203(10) \\
242(25)\end{array}$ & $\begin{array}{l}190 \\
188\end{array}$ \\
\hline & 10 & $\begin{aligned} 24 \\
240\end{aligned}$ & $\begin{array}{l}200 \\
167\end{array}$ & $\begin{array}{l}182 \\
203\end{array}$ & $\begin{array}{l}215(10) \\
209(25)\end{array}$ & $\begin{array}{l}73 \\
70\end{array}$ \\
\hline \multirow{5}{*}{ Span 80} & 0.5 & 24 & 158 & 158 & $200(10)$ & 23 \\
\hline & 1 & $\begin{array}{r}24 \\
240\end{array}$ & $\begin{array}{l}195 \\
176\end{array}$ & $\begin{array}{l}182 \\
199\end{array}$ & $\begin{array}{l}230(10) \\
220(25)\end{array}$ & $\begin{array}{l}28 \\
20\end{array}$ \\
\hline & 3 & $\begin{array}{r}24 \\
240\end{array}$ & $\begin{array}{l}152 \\
163\end{array}$ & $\begin{array}{l}181 \\
179\end{array}$ & $\begin{array}{l}181(40) \\
179(40)\end{array}$ & $\begin{array}{l}37 \\
32\end{array}$ \\
\hline & 5 & $\begin{array}{r}24 \\
240\end{array}$ & $\begin{array}{l}152 \\
144\end{array}$ & $\begin{array}{l}172 \\
155\end{array}$ & $\begin{array}{l}172(40) \\
170(10)\end{array}$ & $\begin{array}{l}47 \\
36\end{array}$ \\
\hline & 10 & $\begin{array}{r}24 \\
240\end{array}$ & $\begin{array}{l}147 \\
144\end{array}$ & $\begin{array}{l}168 \\
168\end{array}$ & $\begin{array}{l}170(25) \\
168(40)\end{array}$ & $\begin{array}{l}30 \\
30\end{array}$ \\
\hline \multirow{3}{*}{ Span 20} & 1 & $\begin{array}{r}24 \\
240\end{array}$ & $\begin{array}{l}131 \\
148\end{array}$ & $\begin{array}{l}189 \\
193\end{array}$ & $\begin{array}{l}189\left(\begin{array}{l}40 \\
204 \\
(25)\end{array}\right.\end{array}$ & $\begin{array}{l}65 \\
77\end{array}$ \\
\hline & 3 & $\begin{array}{r}24 \\
240\end{array}$ & $\begin{array}{l}152 \\
135\end{array}$ & $\begin{array}{l}172 \\
163\end{array}$ & $\begin{array}{l}186(10) \\
174(10)\end{array}$ & $\begin{array}{l}70 \\
73\end{array}$ \\
\hline & 5 & $\begin{array}{r}24 \\
240\end{array}$ & $\begin{array}{l}128 \\
129\end{array}$ & $\begin{array}{l}169 \\
163\end{array}$ & $\begin{array}{l}169(40) \\
163(40)\end{array}$ & $\begin{array}{l}62 \\
65\end{array}$ \\
\hline \multirow{3}{*}{ tween 80} & 1 & $\begin{array}{r}24 \\
240\end{array}$ & $\begin{array}{l}180 \\
131\end{array}$ & $\begin{array}{l}236 \\
193\end{array}$ & $\begin{array}{l}236(40) \\
193(40)\end{array}$ & $\begin{array}{l}50 \\
47\end{array}$ \\
\hline & 3 & $\begin{array}{r}24 \\
240\end{array}$ & $\begin{array}{l}159 \\
164\end{array}$ & $\begin{array}{l}238 \\
238\end{array}$ & $\begin{array}{l}238(40) \\
238(40)\end{array}$ & $\begin{array}{l}57 \\
53\end{array}$ \\
\hline & 5 & $\begin{array}{r}24 \\
240\end{array}$ & $\begin{array}{l}130 \\
137\end{array}$ & $\begin{array}{l}193 \\
196\end{array}$ & $\begin{array}{l}193(40) \\
196(40)\end{array}$ & $\begin{array}{l}60 \\
57\end{array}$ \\
\hline
\end{tabular}

( ) creaming time 


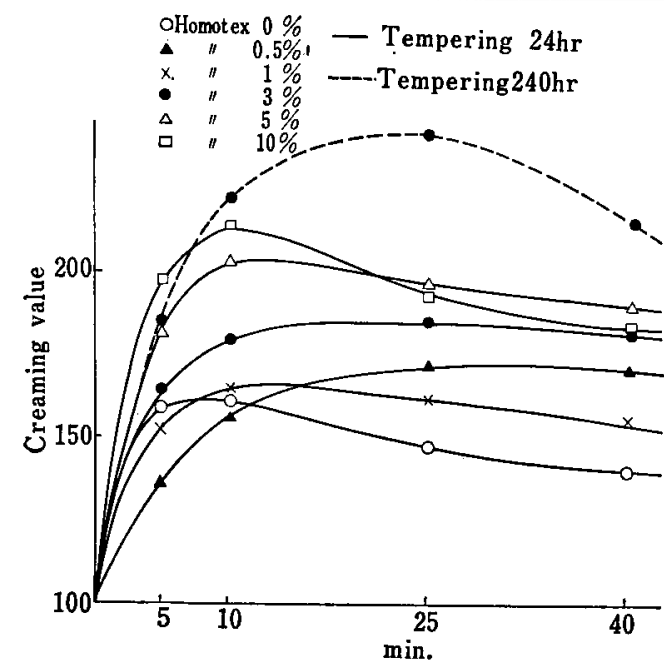

Fig. 1. Change of creaming value of hardened soybean oil with homotex (propylene glycol ester of fatty acid), tempered at $25^{\circ} \mathrm{C}$ for 24 or $240 \mathrm{hr}$.

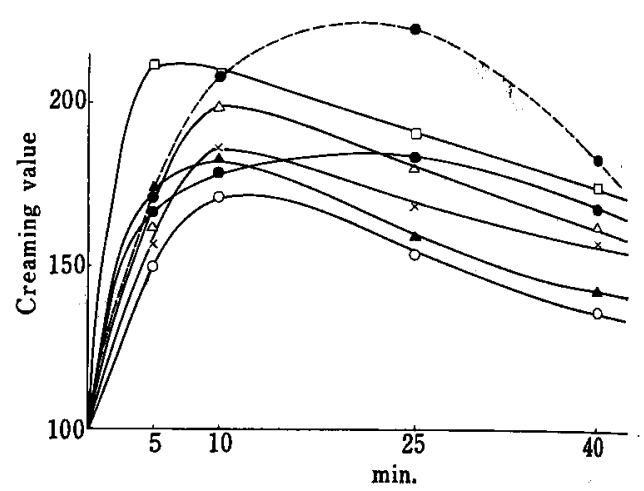

Fig. 2. Change of creaming value of beef tallow with homotex, tempered at $25^{\circ} \mathrm{C}$ for 24 or $240 \mathrm{hr}$.

Table 4. Creaming value and water-sorption index of beef tallow with emulsifiers

\begin{tabular}{|c|c|c|c|c|c|c|}
\hline \multirow[t]{2}{*}{ Emulsfier } & \multirow[b]{2}{*}{ (\%) } & \multirow{2}{*}{$\begin{array}{c}\text { Tempering } \\
\text { time } \\
\text { (hr) }\end{array}$} & \multicolumn{3}{|c|}{ Creaming value } & \multirow{2}{*}{$\begin{array}{l}\text { Water-sorption } \\
\text { index }\end{array}$} \\
\hline & & & $5 \min$ & $40 \min$ & $\operatorname{Max}(\min )$ & \\
\hline \multirow{5}{*}{ Homotex } & 0.5 & 24 & 175 & 144 & $182(10)$ & 8 \\
\hline & 1 & $\begin{array}{l}24 \\
240\end{array}$ & $\begin{array}{l}156 \\
184\end{array}$ & $\begin{array}{l}158 \\
169\end{array}$ & $\begin{array}{l}174(10) \\
209(10)\end{array}$ & 7 \\
\hline & 3 & $\begin{array}{r}24 \\
240\end{array}$ & $\begin{array}{l}166 \\
171\end{array}$ & $\begin{array}{l}168 \\
183\end{array}$ & $\begin{array}{l}183(25) \\
217(25)\end{array}$ & $\begin{array}{l}8 \\
*\end{array}$ \\
\hline & 5 & $\begin{array}{r}24 \\
240\end{array}$ & $\begin{array}{l}162 \\
188\end{array}$ & $\begin{array}{l}164 \\
174\end{array}$ & $\begin{array}{l}199(10) \\
220(10)\end{array}$ & ${ }^{17}$ \\
\hline & 10 & $\begin{array}{r}24 \\
240\end{array}$ & $\begin{array}{l}212 \\
197\end{array}$ & $\begin{array}{l}175 \\
167\end{array}$ & $\begin{array}{l}212 \text { (5) } \\
215(10)\end{array}$ & 22 \\
\hline \multirow{5}{*}{ Span 80} & 0.5 & 24 & 154 & 161 & $177(25)$ & 10 \\
\hline & 1 & $\begin{array}{r}24 \\
240\end{array}$ & $\begin{array}{l}175 \\
183\end{array}$ & $\begin{array}{l}168 \\
170\end{array}$ & $\begin{array}{l}197(10) \\
213(10)\end{array}$ & ${ }_{*}^{18}$ \\
\hline & 3 & $\begin{array}{r}24 \\
240\end{array}$ & $\begin{array}{l}153 \\
157\end{array}$ & $\begin{array}{l}171 \\
176\end{array}$ & $\begin{array}{l}176(25) \\
182(25)\end{array}$ & $\stackrel{38}{*}$ \\
\hline & 5 & $\begin{array}{r}24 \\
240\end{array}$ & $\begin{array}{l}156 \\
157\end{array}$ & $\begin{array}{l}173 \\
165\end{array}$ & $\begin{array}{l}173(40) \\
171(10)\end{array}$ & 50 \\
\hline & 10 & $\begin{array}{r}24 \\
240\end{array}$ & $\begin{array}{l}169 \\
168\end{array}$ & $\begin{array}{l}177 \\
170\end{array}$ & $\begin{array}{l}177(40) \\
176(10)\end{array}$ & $\stackrel{23}{*}$ \\
\hline \multirow{3}{*}{ Span 20} & 1 & $\begin{array}{r}24 \\
240\end{array}$ & $\begin{array}{l}136 \\
131\end{array}$ & $\begin{array}{l}191 \\
222\end{array}$ & $\begin{array}{l}214(25) \\
222(40)\end{array}$ & $\stackrel{70}{*}$ \\
\hline & 3 & $\begin{array}{r}24 \\
240\end{array}$ & $\begin{array}{l}143 \\
159\end{array}$ & $\begin{array}{l}171 \\
193\end{array}$ & $\frac{171}{210}\left(\begin{array}{l}40 \\
25\end{array}\right)$ & $\begin{array}{l}73 \\
72\end{array}$ \\
\hline & 5 & $\begin{array}{r}24 \\
240\end{array}$ & $\begin{array}{l}125 \\
167\end{array}$ & $\begin{array}{l}169 \\
193\end{array}$ & $\begin{array}{l}169(40) \\
207(25)\end{array}$ & ${ }^{90}$ \\
\hline \multirow{3}{*}{ Tween 80} & 1 & $\begin{array}{r}24 \\
240\end{array}$ & $\begin{array}{l}141 \\
138\end{array}$ & $\begin{array}{l}197 \\
193\end{array}$ & $\begin{array}{l}197(40) \\
193(40)\end{array}$ & 67 \\
\hline & 3 & $\begin{array}{r}24 \\
240\end{array}$ & $\begin{array}{l}138 \\
130\end{array}$ & $\begin{array}{l}225 \\
189\end{array}$ & $\begin{array}{l}225(40) \\
189(40)\end{array}$ & $\begin{array}{l}82 \\
65\end{array}$ \\
\hline & 5 & $\begin{array}{r}24 \\
240\end{array}$ & $\begin{array}{l}146 \\
184\end{array}$ & $\begin{array}{l}203 \\
223\end{array}$ & $\begin{array}{l}203(40) \\
234(25)\end{array}$ & 87 \\
\hline
\end{tabular}

\footnotetext{
* measurment impossible
} 
は大きくなる。0〜 $\%$ \%ではクリーム化後 $10 \mathrm{~min}$ で最 高値を示すが 10\% 添加すると 5 min で最高值を示し， 以後はやや低くなる傾向を示す。

また, $240 \mathrm{hr}$ テンバリングした牛脂は Table 4 亿示 すようにクリーミング価は上昇し，1および3\%添加し た試料で $20 \%$ 增加する。

iii）硬化鲸油

Fig. 3 亿示すように無添加試料ではクリーム化後 $25 \min$ で最高值を示すが, homotex を添加すると 5 〜 $10 \min$ ですでに良好な抱気性を示し, 添加による勃果 が認められる。しかし $25 \mathrm{~min}$ 以後は硬化大豆油ほどの 差がみとめられず 無添加と $10 \%$ 添加試料 の最高值で比 较すると $7 \%$ 増加にすぎない。

$240 \mathrm{hr}$ テンパリング 後のクリーミング価は Table 5 に示すように，1\%添加では $25 \% ， 3 \%$ 添加試料では 16\%增加し，この場合もテンパリング软果が認められ

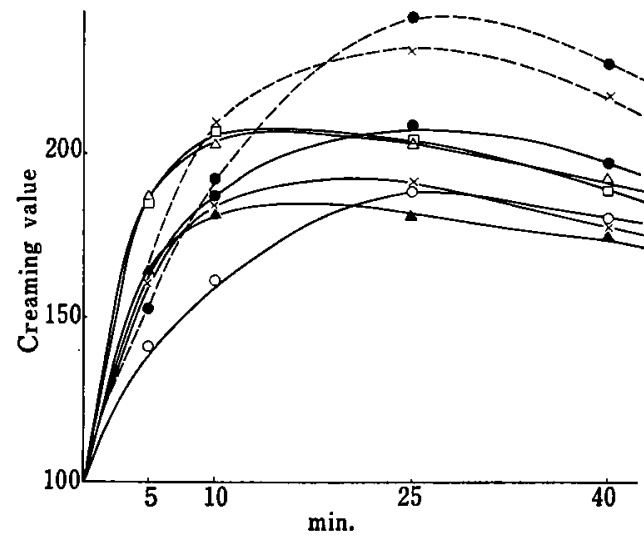

Fig. 3. Change of creaming value of hardened whale oil with homotex, tempered at $25^{\circ} \mathrm{C}$ for 24 or $240 \mathrm{hr}$. る。

Table 5. Creaming value and water-sorption index of hardened whale oil with emulsifiers

\begin{tabular}{|c|c|c|c|c|c|c|}
\hline \multirow[t]{2}{*}{ Emulsifier } & \multirow[b]{2}{*}{$(\%)$} & \multirow{2}{*}{$\begin{array}{l}\text { Tempering } \\
\text { time } \\
\text { (hr) }\end{array}$} & \multicolumn{3}{|c|}{ Creaming value } & \multirow{2}{*}{$\begin{array}{l}\text { Water-sorption } \\
\text { index }\end{array}$} \\
\hline & & & $5 \mathrm{~min}$ & $40 \mathrm{~min}$ & $\operatorname{Max}(\min )$ & \\
\hline \multirow{5}{*}{ Homotex } & 0.5 & 24 & 165 & 175 & $192(25)$ & 5 \\
\hline & 1 & $\begin{array}{r}24 \\
240\end{array}$ & $\begin{array}{l}163 \\
154\end{array}$ & $\begin{array}{l}178 \\
218\end{array}$ & $\begin{array}{l}187(10) \\
233(25)\end{array}$ & 10 \\
\hline & 3 & $\begin{array}{r}24 \\
240\end{array}$ & $\begin{array}{l}162 \\
155\end{array}$ & $\begin{array}{l}199 \\
227\end{array}$ & $\begin{array}{l}210(25) \\
243(25)\end{array}$ & $\begin{array}{l}65 \\
66\end{array}$ \\
\hline & 5 & $\begin{array}{r}24 \\
240\end{array}$ & $\begin{array}{l}188 \\
173\end{array}$ & $\begin{array}{l}194 \\
225\end{array}$ & $\begin{array}{l}204(25) \\
225(40)\end{array}$ & 193 \\
\hline & 10 & $\begin{array}{r}24 \\
240\end{array}$ & $\begin{array}{l}186 \\
173\end{array}$ & $\begin{array}{l}190 \\
218\end{array}$ & $\begin{array}{l}207(10) \\
229(25)\end{array}$ & $\begin{array}{r}110 \\
*\end{array}$ \\
\hline \multirow{5}{*}{ Span 80} & 0.5 & 24 & 188 & 188 & $203(10)$ & 13 \\
\hline & 1 & $\begin{array}{r}24 \\
240\end{array}$ & $\begin{array}{l}180 \\
166\end{array}$ & $\begin{array}{l}192 \\
210\end{array}$ & $\begin{array}{l}205(10) \\
220(25)\end{array}$ & 20 \\
\hline & 3 & $\begin{array}{r}24 \\
240\end{array}$ & $\begin{array}{l}191 \\
160\end{array}$ & $\begin{array}{l}183 \\
165\end{array}$ & $\begin{array}{l}193(10) \\
187(25)\end{array}$ & 80 \\
\hline & 5 & $\begin{array}{r}24 \\
240\end{array}$ & $\begin{array}{l}174 \\
165\end{array}$ & $\begin{array}{l}188 \\
169\end{array}$ & $\begin{array}{l}193(25) \\
187(25)\end{array}$ & 117 \\
\hline & 10 & $\begin{array}{r}24 \\
240\end{array}$ & $\begin{array}{l}164 \\
164\end{array}$ & $\begin{array}{l}200 \\
203\end{array}$ & $\begin{array}{l}200(40) \\
206(25)\end{array}$ & $*$ \\
\hline \multirow{3}{*}{ Span 20} & 1 & $\begin{array}{r}24 \\
240\end{array}$ & $\begin{array}{l}135 \\
133\end{array}$ & $\begin{array}{l}203 \\
201\end{array}$ & $\begin{array}{l}203(40) \\
201(40)\end{array}$ & 62 \\
\hline & 3 & $\begin{array}{r}24 \\
240\end{array}$ & $\begin{array}{l}143 \\
138\end{array}$ & $\begin{array}{l}187 \\
186\end{array}$ & $\begin{array}{l}187(40) \\
186(40)\end{array}$ & 75 \\
\hline & 5 & $\begin{array}{r}24 \\
240\end{array}$ & $\begin{array}{l}137 \\
126\end{array}$ & $\begin{array}{l}175 \\
177\end{array}$ & $\begin{array}{l}175(40) \\
177(40)\end{array}$ & 100 \\
\hline \multirow{3}{*}{$T_{\text {ween }} 80$} & 1 & $\begin{array}{r}24 \\
240\end{array}$ & $\begin{array}{l}142 \\
135\end{array}$ & $\begin{array}{l}227 \\
199\end{array}$ & $\begin{array}{l}235(25) \\
199(40)\end{array}$ & 55 \\
\hline & 3 & $\begin{array}{r}24 \\
240\end{array}$ & $\begin{array}{l}138 \\
145\end{array}$ & $\begin{array}{l}203 \\
215\end{array}$ & $\begin{array}{l}203(40) \\
215(40)\end{array}$ & $\begin{array}{l}58 \\
61\end{array}$ \\
\hline & 5 & $\begin{array}{r}24 \\
240\end{array}$ & $\begin{array}{l}147 \\
138\end{array}$ & $\begin{array}{l}203 \\
210\end{array}$ & $\begin{array}{l}203(40) \\
210(40)\end{array}$ & 57 \\
\hline
\end{tabular}

* measurment impossible 
硬化大豆油に homotex 添加すると結晶成長を抑制 する効果のあることはさきの報告" $の$ X線回折結果から も明らかで，この場合多形の転移のおそいほどクリーミ ソグ性はよいようにみえる。しかし牛脂, 硬化鯨油の場 合は転移にほとえど関与しないにもかかわらず，添加量 の增すに従ってクリーミング性も向上することから，固 体脂そのものの性質よりも乳化郕の種類と量に関連する ものと思われる。この点寺田ら ${ }^{10)}$ も゚゙ピレングリコー ル脂肪酸エステル,ポリオキシェチレン脂肪酸エステル， ソルビタン脂肪酸エステルなどによってクリーミング性 は固体脂に依存することは少なくなったとのべている。

さきの報告9)で硬化鯨油>牛脂>硬化大豆油の順にク リーミング性が良好であると報告したが $24 \mathrm{hr}$ テンパ リングでの最高值でつぎに示すように， homotex を添 加すると硬化大豆油>牛脂>硬化觡油の順となり完全に 逆になる。

Homotex 10\% 添加脂のクリーミング価および無 添加試料汶対する上昇率

\begin{tabular}{|c|c|c|c|}
\hline & 無添加 & $10 \%$ 添加 & 上界率 \\
\hline 硬 化大豆油 & 163 & 215 & $132 \%$ \\
\hline 牛 & 175 & 212 & 121 \\
\hline 硬 化 䖷 油 & 193 & 207 & 107 \\
\hline
\end{tabular}

テンパリンク゚効果について比較すると Fig. 1, 2, 3 和 よび数字でつぎに示すように，硬化大豆油>牛脂>硬化 鯨油の順に㚳果が認められる。

Homotex 3\% 添加脂のクリーミング価およびテン バリング $24 \mathrm{hr}$ に対する' $240 \mathrm{hr}$ の場合の上昇率

\begin{tabular}{|c|c|c|c|c|c|}
\hline & $3 \%$ 添 & & $24 \mathrm{hr}$ & $240 \mathrm{hr}$ & 上其革 \\
\hline 硬 & 化 大 豆 & 油 & 185 & 233 & $126 \%$ \\
\hline 牛 & & 脂 & 183 & 217 & 119 \\
\hline 硬 & 化 䭘 & 油 & 210 & 243 & 116 \\
\hline
\end{tabular}

したがってただ単に乳化埥だけの問題でもなく，固形 脂の種類，組成などとの相乘勃果によるものと思われる が，個々の点についてはまだ検討を要する。

(2) span 80, span 20 添加試料

i) 硬化大豆油

span 80 を添加, $25^{\circ} \mathrm{C} 24 \mathrm{hr}$ テンパリングした試料の クリーミング洒は Fig.4 に示すとおりである。homotex 添加の場合とやや異なり，むしろ添加量が 0.5，1\% と 少ないとクリーム化徐 5 〜10 min では 良好な抱気性を

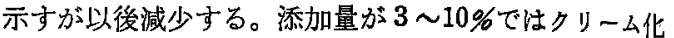
初期では無添加試料との差が認められないが，以後持続 性が良好で無添加試料との差が認められるものの， homotex の場合のように添加した量の差による明確な 差異は認められない。また span 20 も同様の結果が得ら れた。

$240 \mathrm{hr}$ テンパリングした場合のクリーミング価住 Table 3 に示すように，24 hr 処理した試料より低い値 を示し効果が認められない。 homotex 洁晶成長抑制 効果 ${ }^{3) か ゙ あ り ， ~} \operatorname{span} 80$ は促進する2 この場合結晶形とも関連があるのかもしれない。すな ち転移が進むほどクリーミング性はおとるため，クリー 么化初期では固体脂そのものの性質が多く現われるため 添加量の少ない方が良好であった。しかし添加量の多い

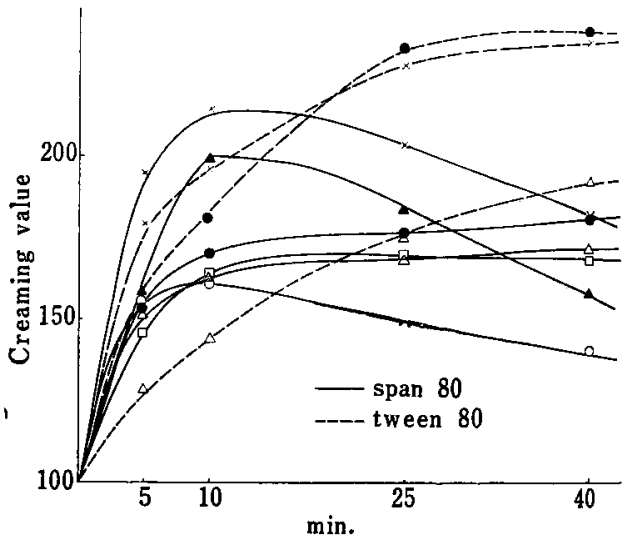

Fig. 4. Change of creaming value of hardened soybean oil with span 80 and tween 80 , tempered at $25^{\circ} \mathrm{C}, 24 \mathrm{hr}$.

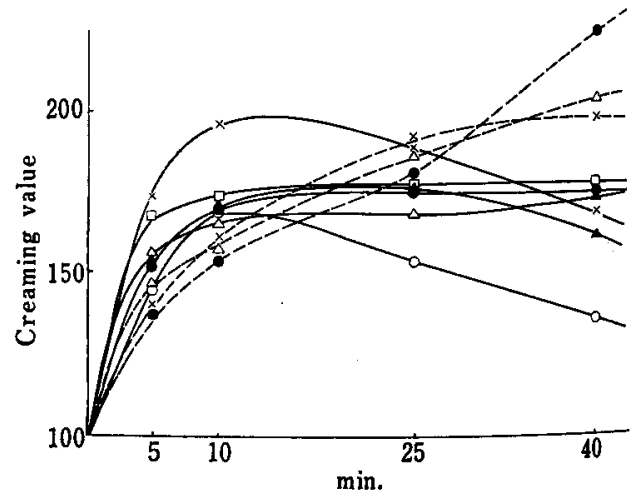

Fig. 5. Change of creaming value of beef tallow with span 80 and tween 80 , tempered at $25^{\circ} \mathrm{C}, 24 \mathrm{hr}$. 
方が持続性が良好なのは, 以後は乳化绪としての性質が 多く現われたためと思われる。

ii) 牛 脂

Fig. 5 に示すように, span 80 を $0.5 \%$ 添加した試料 のみ Fig. 4 硬化大豆油の場合と同様の傾向を示す。し かし 1〜10\%添加した牛脂ではクリーム化後 $5 \sim 10 \mathrm{~min}$ では無添加試料との差は認められないが以後持続性が良 好で，無添加との差は明確なものの，添加量による差は 認められない。

$240 \mathrm{hr}$ テンパリングした場合は Table 4 に示すよう に, span 80 1，3\% 添加したものは効果がみられる が，添加量が増すと差がなくなる。 span 20 はいずれる クリーミング洒はかなり大きくなりテンパリング効果が 認められる。

iii) 硬化鲸油

$\operatorname{span} 80, \operatorname{span} 20$ を添加した試料のクリーミング 低 は，ともにクリーム化後 5〜10 min では無添加のもの より大きい值を示すものの，添加量順位と逆の傾向を示 す。 $25 \mathrm{~min}$ 以後は無添加試料とほとえど差がみられな いまた Table 5 に示すようにテンパリング効果はま ったくみられず，同じ動物脂でも傾向が異なる。

(3) tween 80 添加試料

Fig. 4 に示したように, tween 80 を添加した硬化大豆 油は最初から，クリーム化時間の増すにつれて上昇し， 前述 homotex, spanを添加したものとはまったく異な る变化を示す。しかも最高值でも比較すると homotex とほほ同等のクリーミング性を示すが， homotex 添加 試料ではクリーム化 $10 \mathrm{~min}$ で最高值を示すのに対し tween 80 は $40 \mathrm{~min}$ で最高を示した。したがってクリ

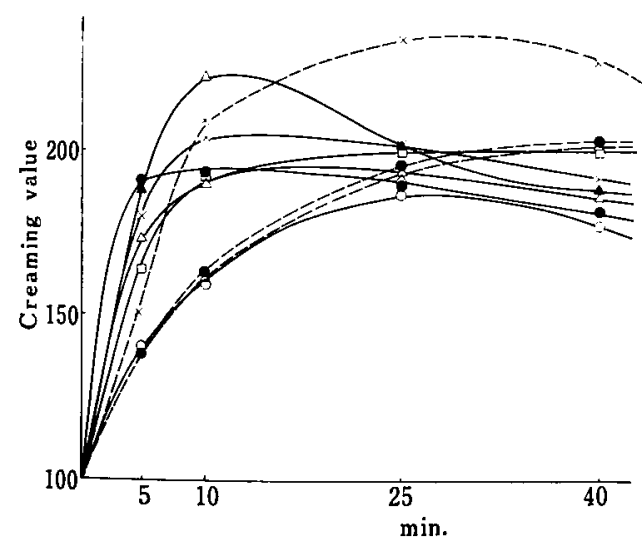

Fig. 6. Change of creaming value of hardened whale oil with span 80 and tween 50 , tempered at $25^{\circ} \mathrm{C}, 24 \mathrm{hr}$.
一ム化 $40 \mathrm{~min}$ では Table 3 に示すように前述 3 釈化剂 のいずれよりも高い值を示す。しかしテンパリング効果 はみられなかった。

牛脂の場合は Fig. 5 に示すように, クリーム化 10 $\min$ をでは $\operatorname{span} 80$ を添加したものより低い值を示す ものの, Fig. 4 と同様クリーム化時間とともに上昇す る。しかも homotex 添加試料より大きい值を示しクリ ーミング性にすぐれている。

硬化鯨油は Fig. 6 に示すように 3, 5\% 添加では 25 min まで無添加のものとほとえど変らないが以後わずか に上昇する。しかし $1 \%$ \%添加試料はかなり大きい值を示 すものの，テンパリング効果はみられない。

したがってこの場合は固形脂の種類や性質よりも乳化 戍としての效果が非常に大きいことを示している。

(4) 添加量とクリーミング価の関連

i) Homotex 添加試料

Fig. 7(A) はクリーミング㜀最高值と添加量の関連に ついて図示したものである。homotex 添加試料ではテ ンパリング $24 \mathrm{hr}$ では添加量の増えるにしたがってクリ ーミング価も大きくなることを示し，120，240 hr では 3〜 $5 \%$ 添加したものが良好であることを示している。 牛脂の場合む Fig. 7(B)にみるように, 硬化大豆油の 場合ほど明嘹ではないが，テンパリング $24 \mathrm{hr}$ では添加 量に応じて増加するが $120,240 \mathrm{hr}$ では 3〜 $5 \%$ 添加し たものが大きい值を示す。硬化鯨油はいずれも $3 \%$ 添加 した場合クリーミング性が良好であることを示す。さき の報告9)でクリーミング性のよくないレシチンを添加し た実験では $3 \sim 5 \%$ 最低值を示したことと対比すると 興味ある結果である。

ii) $\operatorname{span} 80$ 添加試料

Fig. 7(A) 抢よび(B) に示したように，1\%添加した 場合がもっともクリーミング性が良好で，3\%以上添加 してもさほどの効果がみられないことを示している。 硬化鯨油は Fig. 7(C) に示すようにクリーミング価自 体はレシチンの場合より大きいが $3,5 \%$ 添加量のもの が比較的効果の少ないこと宗している。

\section{3. 吸水量指数}

(1) Homotex 添加試料

$25^{\circ} \mathrm{C}, 24 \mathrm{hr}$ テンパリングし，40 min クリーム化した 硬化大豆油の吸水性は Table 3.示したように，5\%ま では添加量に応じて多くなり，レシチンの場合より吸水 量指数は大である。しかし添加量が 10\%になると逆に 减少する。しかもテンパリング勃果はほとえど認められ ず, $240 \mathrm{hr}$ テンパリングしたものも変らない。 

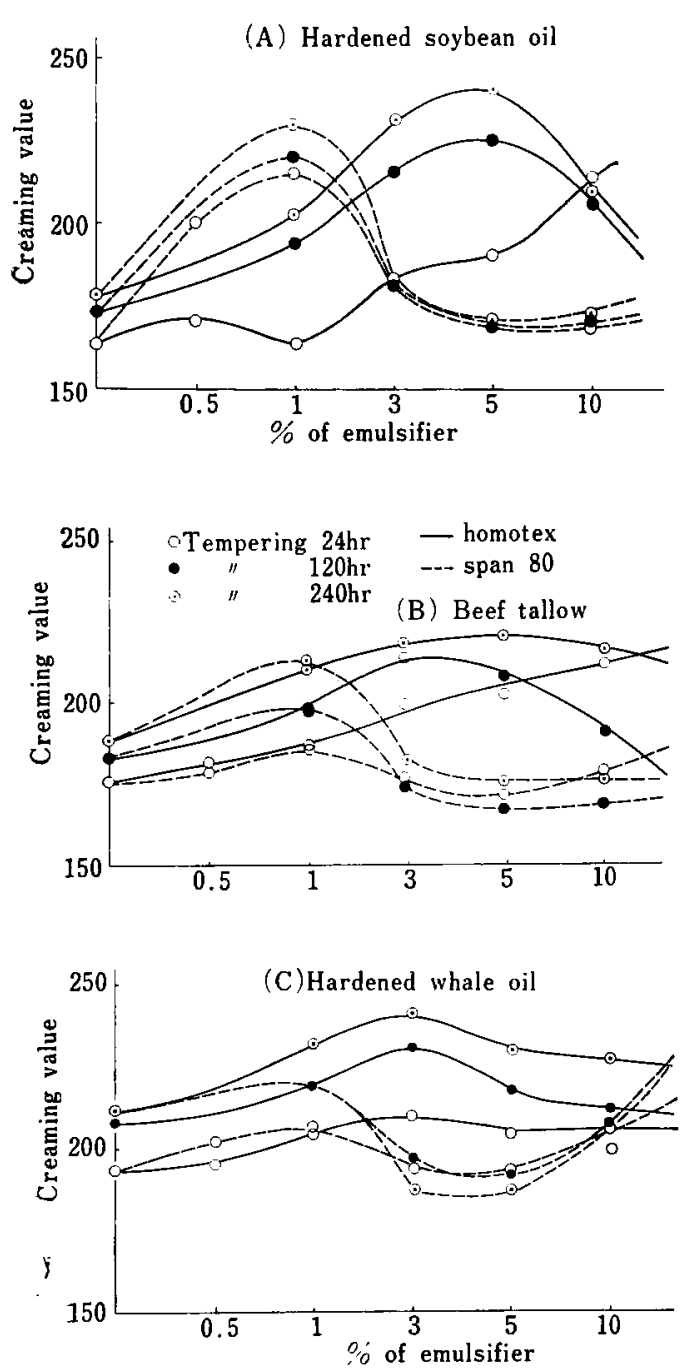

Fig. 7. Relation between creaming value and amount of added homotex or span 80 .

硬化鯨油の場合は Table 5 に示したように，硬化大豆 油と同様の傾向を示し，5\% 添加ではレシチンより吸水 性は良好であるが $10 \%$ 添加試料では減少する。また $120 ， 240 \mathrm{hr}$ テンパリングしたものは吸水量の飽和点が 明確でなく，吸水量指数を求めることができなかった。

牛脂の場合, レシチンを添加すると吸水性訬非常によ くなると報告9! したが, Table 4 に示したように homotex の場合は効果がほとえどみられない。しかるテンパ リング時間が長くなると，硬化鯨油の場合同様飽和点が 明確でない。したがってテンパリンダ温度を $25^{\circ} \mathrm{C}$ より 低くして測定を行ならとあるいは関連が得られるかもし
れない。

(2) $\operatorname{span} 80$, span 20, tween 80 添加試料 span 80 を添加した硬化大豆油，牛脂の吸水性はよく ないが，硬化鯨油は添加量が5\%までは添加量に応じて 吸水量指数は大きくなるが homotex よりは劣る。

span 20 添加の効果は span 80 よりは良好で，しか も添加量による差がほとえどみられない。 tween 80 の 場合も span 20 とほほ同様の吸水量指数を示す。

硬化大豆油にこれらの乳化剂を添加した場合， $240 \mathrm{hr}$ テンパリングしたものむほとんど変らす，テンパリンダ 効果は認められない。この場合む牛脂, 硬化鲸油はテン パリング時間を長くすると測定不可能で, 前述 homotex の場合と同様のことがい光る。この場合吸水性る固形脂 の種類によりやや差があるものの乳化剂の差の方が大き く, 親水性のものほどの吸水性の大きいことを示してい る。

\section{要 約}

前報同様 3 種の固形脂に homotex, span 80 を 0.5 , $1,3,5,10 \%$ ， span 20 および tween 80 を 1, 3, 5\% 添加し， $25^{\circ} \mathrm{C} に 24 ， 120,240 \mathrm{hr}$ テンパリングを行な い,クリーミング洒拉よび吸水量指数の測定を行なった ところつぎのような結果を得た。

(1) homotex を添加すると添加量に応じてクリーミ ング価が著しく増大した。固形脂別にみると硬化大豆 油>牛脂>硬化鯨油の順にクリーミング性は良好であっ た。

（2）またテンパリング効果は硬化大豆油>牛脂>硬化 鯨油の順に認められた。

(3) $\operatorname{span} 80$, span 20 を 10\% 添加した試料のク リーミング価はクリーム化 $10 \mathrm{~min}$ までは無添加のすの とほとんど変らない。しかし持続性が良好で $40 \mathrm{~min} て ゙$ は無添加試料との差は認められるものの, 添加量のちが いによる差は認められない。

(4) tween 80 を添加した試料のクリーム化初期のク リーミング価は spanより低いが，洔間の增加に従って 上昇, $40 \mathrm{~min}$ では homotex 添加の場合より大きい值 を示す。

(5) 添加量とクリーミング伍の関連についてみると， homotex अ 3 5\%， span 80 は 1\% 添加した場合加 もっとも大きい值を示す。

(6) Homotex 0.5 5\% 添加した硬化大豆油, 硬 化鯨油の吸水性は, レシチンの場合と同様良好である が，10\%になると低くなる。しかし牛脂の場合は良好で 
ない。

(7) span 80 定添加した硬化大豆油, 牛脂の吸水性は よくない。 $\operatorname{span} 20$, tween 80 は span 80 より吸水性 は良好であるが添加量による差が認められない。

終りに，本研究の分析に協力された東海大学の佐藤正 光君に樑謝する。

\section{文献}

1) 新谷 县・木下葉子 - 今村正男 - 岡田正和 - 松本 太郎：油化学, 19, 473 (1970).

2）新谷 县 - 守瀬恵美子 - 今村正男 - 岡田正和 - 松 本太郎：食品工誌，18，583(1971)；18, 589 (1971).

3) 新谷 惧 - 丸山武紀 - 今村正男 - 岡田正和 - 松本
太郎：食品工誌, 20, 182, 191, 199 (1973)

4) 中沢君敏・島田哲夫・梅沢 貢：油化学， 4, 57 (1955).

5) Rusch, D.H. and Truax, H.M.: J. Am.pil Chemist's Soc., 48, 173 (1971).

6) Moncrieff, J.: Baker's Dig., 44, 60 (1970).

7) Ludwig, K. G. and Gakenheimer, W.C.: FetteSeifen Anstrichmittel, 69, 285 (1965).

8) Titus, T.C., Wiancko, N. N., Barbour, H.F. and Mickle, J. B.: Food Technol., 22, 115 (1968).

9) 丸山武紀・木下葉子・新谷 惧-今村正男：食品 工誌, 20, 265 (1973)

10）寺田喜巳男 - 河野博繁: 油化学, 18, 543 (1969). (昭和 47 年 11 月 30 日受理) 